\title{
Inter-jurisdictional Fiscal Competition: a review of the literature and policy recommendations
}

\author{
SERGIO GUIMARÃES FERREIRA* \\ RICARDO VARSAN O** \\ JOSÉ ROBERTO AFONSO***
}

This paper surveys the literature on fiscal competition. We consider tax and expenditure competition in a more general set up where different jurisdictions within a federation may compete in the provision of public goods in order to attract some residents (Tiebout, 1956) and expel others (Brueckner, 1999); and/or for business. We address the vast literature on welfare gains or losses of these types of competition. Then, we discuss the empirical evidence, focusing on estimates of the sensitiveness of production factors to tax differentials and on the importance of the strategic interdependence among jurisdictions. W e combine econometric studies with some case studies. Last we discuss the design of mechanisms to cope with fiscal competition, especially under a moreglobal environment where factors become more mobile.

Key-words: Fiscal Federalism; Tax Differentials; Factor M obility.

JEL Classification: H 77; H 73; F2

* IBM EC/RJ, Av. Rio Branco 108, s/ 906, Rio de Janeiro. E-mail: sergiogu@terra.com.br.

** Fundo M onetário Internacional - FM I, Departamento de Finanças Públicas. E-mail: soniaericardo@verizon.net.

*** Assessoria da Câmara dos Deputados, Palácio do Congresso N acional, Edifício Principal, Praça dos Tres Poderes, Brasilia. e-mail: ze.afonso@terra.com.br

Submetido: M arço 2004; A ceito: Agosto 2004. 


\section{INTRODUCTION}

Federalism may be defined as a system in which a central government and a number of decentralized units - which are, to some degree, autonomous cooperate - to some extent - to attain common goals. Though some may prefer a stricter definition, this one is convenient for treatment of fiscal competition. First, it includes not only countries with federal constitutions but also those where public services provision and taxation are decentralized, as well as sovereign units forming an economic union. Second, it makes clear that fiscal competition is an event related to one of the extremes of the continuum of possible federal arrangements, namely, the case in which autonomy is fully exerted and no coordination exists among the units ${ }^{1}$.

Interjurisdictional competition may be passive, in the sense that the independent actions do not intend to influence conditions faced by the unit or by other jurisdictions; or active, meaning that the tax or expenditure is deliberately used as an instrument to pursue some goal. Fiscal competition may be horizontal, when it involves governments at the same level; and vertical, when higher and lower levels of government are competitors. In all cases, one cannot presume whether fiscal competition is welfare enhancing or harmful.

This is the main question addressed by the vast and fast growing literature on fiscal competition, which originates from a seminal article by Tiebout (1956) and from $W$ allace $O$ ates's systematization of the then existing economic theory on federalism ( $O$ ates, 1972). There is not a simple answer to the question. The general inference is that the answer depends on several aspects, prominent among them the objectives of competing governments; over what they are competing; how they compete; the behavior of economic agents, especially their mobility in response to fiscal stimuli; and the characteristics of the economic environment, particularly the possibility of interjurisdictional externalities arising from government actions.

This article does not intend to be a comprehensive survey of the huge literature on fiscal competition but rather to extract from it typologies and some analyses and results that may help to organize a debate on the subject. Therefore, the next section deals with the objects and the instruments of fiscal competition. Section 3 collects some empirical evidence on the existence of fiscal competition and on the reaction of economic agents to interjurisdictional differences in tax burdens and benefits from public spending. Section 4 considers the main tools that may be used to avoid or counteract possible harmful effects of fiscal competition. Section 5 summarizes the argument presented in the paper and speculates on the effects of globalization on the roles of central and decentralized government units.

${ }^{1}$ Fiscal competition occurs in a situation in which each federate unit independently decides a tax or expenditure policy. This does not preclude concomitant cooperation in other fiscal and non-fiscal policies. 
The traditional theory of fiscal federalism discusses the assignment of the economic functions of the public sector - allocation, distribution and stabilization - to different levels of government. The general conclusion is that central governments should be responsible for macroeconomic stabilization and income redistribution as well as for the provision of national public goods, i.e., those which benefit area is the whole country (or economic union)2. The economic case for decentralized governments rests on the existence of public goods which benefits are limited to a specific area or subset of the population (local public goods).

The financing of local public goods in federations comes mainly from three sources: taxes assigned to lower level governments, intergovernmental grants and debt. Grants are inherently cooperative instruments, which, if well designed, can serve several different objectives in a federation. Decentralized taxation, on the other hand, unless some degree of harmonization exists, is independently exerted and may distort resource allocation when economic agents are mobile. To avoid distortions, theory recommends that only benefit taxation should be applied to potentially mobile tax bases. But, in the real world, non-benefit taxation is the norm, being frequently used as an instrument of active governmental competition. According to its object, fiscal competition may be classified in three categories. First, decentralized units compete in the provision of a bundle of public goods and services, trying to improve its quality, reduce its costs and adjust supply to match residents' preferences. Second, they compete for funds, to finance the provision of public goods at the lowest possible tax price for residents. And third, competition may have as its object business investment, to increase production, the level of employment and income within the unit.

\subsection{Competition in the provision of public goods}

Competition in the provision of public goods is the subject of the original Tiebout model (Tiebout, 1956) as well as of more recent and richer models ( 0 ates and Schwab, 1988), which conclude, under a set of strong assumptions, that this kind of competition is efficiency improving. In brief, uncoordinated decisionmaking would result in the provision of a variety of fiscal packages (a bundle of public goods plus a tax price), so that mobile individuals (or firms) may enjoy their preferred package by choosing as residence the locality where it is provided

\footnotetext{
${ }^{2}$ Typically, decentralized units do not have monetary policy instruments and, being highly open, are unable to influence macroeconomic conditions using fiscal devices. Income redistribution policies, on the other hand, are constrained by the mobility of economic agents. Higher income households would tend to leave a jurisdiction and an inflow of poor families would be stimulated if a tax-the-richbenefit-the-poor policy were locally pursued. $\mathrm{N}$ otwithstanding, decentralized government units often perform functions, financed by the wealthy or by all, which benefits accrue mainly to the poor; and local programs that provide cash or in-kind relief to the poor are not uncommon.
} 
("voting with the feet"). Competition is also said to promote innovation in the provision of public goods and its diffusion and, by benchmarking with other governments, to minimize organizational costs of the public sector and to reinforce accountability. Shah (2001) reports that in Chile and Canada, school financing mechanisms encourage informal benchmarking by citizens to guide their choice of schools.

$M$ odels that relax some of the strong assumptions mentioned in the preceding paragraph show the reverse side of the coin. For instance, models employing game theory drop the assumption that there is no strategic interaction in response to policies of neighboring jurisdiction and find outcomes that involve suboptimal levels of public outputs (Wildasin, 1988).

W hen strategic behavior exists, competition may stimulate the underprovision of merit goods and social policies. In Brazil, for example, municipalities are responsible for a large share of expenditures in public health, financed partly by earmarked federal block grants and partly by their own revenues. In metropolitan areas, individuals commute frequently across cities and since eligibility for public health services is not attached to residence, municipalities providing better quality services are prone to attract clients from surrounding cities. In fact, Ferreira (2002) found that municipalities neighboring the city of Rio de Janeiro spend in public health services less than the expected value, both in per capita terms and as a percentage of their respective tax revenues. The government of the city of $\mathrm{R}$ io de Janeiro, in turn, did not seem to take into account the positive externalities that its expenditures generate. The overall result is underprovision of public health services in the metropolitan area.

A nother interesting example is provided by the United States welfare system. A 1996 reform decentralized w elfare policy. States have now a large degree of autonomy to decide forms and levels of assistance to the poor. H owever, if a state decides to increase its welfare benefits, it runs the risk of attracting the poor from other localities, whose immigration increases state welfare expenditures but not the income tax revenue. To avoid becoming a "w elfare magnet" - and, hence, increase the tax burden over the state's better-off residents - each state tends to reduce the value of the benefits provided. As Brueckner (1999) points out, "because the concern about welfare migration depresses benefits in every state, no state succeeds in repelling the poor by keeping its benefits low, and each ends up being less generous than it would have been in the absence of migration". This reasoning points to a downward bias in the value of welfare benefits under current institutional arrangements.

$O$ ates (1999) recognizes the shortcomings of decentralized systems of relief to the poor, but argues that a decision was made to accept the downward bias as a price to be paid for the possibility of abandoning unsatisfactory federal welfare programs and looking for superior policy alternatives. He asserts "in a setting of imperfect information with learning-by-doing, there are potential gains from experimentation with a variety of policies for addressing social and economic problems. And a federal system may offer some real opportunities for encouraging 
such experimentation and thereby promoting 'technical progress' in public policy". $\mathrm{H}$ e names policy experimentation in decentralized units "laboratory federalism".

\subsection{Competition for funds}

The second category of fiscal competition - competition for funds, to finance the provision of public goods to residents at the lowest possible tax price includes policies that intend to enlarge tax bases (or revenues) as well as disputes for usually scarce costless or low-cost funds provided by a higher level of government.

Where the personal income tax is assigned to subnational governments, these units may attract the wealthy from other jurisdictions by reducing tax rates or by providing a package of public goods tailored to their taste. Insofar as pure (or nearly so) public goods are provided - and, therefore, additional consumers do not imply increase in the total cost of production - newcomers reduce the tax bill of the other residents. This beggar-thy-neighbor policy, if successful, would imply higher tax prices for public goods elsewhere and, therefore, their underprovision. It might also weaken the power of income redistribution policies. $\mathrm{O} n$ the other hand, fiscally induced mobility may result in more homogeneous population in each jurisdiction and lead to a closer match between provision of and demand for local public goods.

Switzerland offers the best conditions for undertaking empirical analysis of these points. Though there is a small federal income tax, cantons have the basic power to tax income and wealth while local jurisdictions levy property taxes and a surcharge on cantonal direct taxes. Public spending is very decentralized and social assistance is a concern only of local and cantonal governments ${ }^{3}$.

Feld and K irchgässner (2000) addressed their work to the question whether fiscal competition exists and what are its effects. They conclude that there is competition both among cantons and among cities; that taxes are more important instruments than social transfers; and that tax competition is stronger at the local than at the cantonal level. H igh-income earners choice of the place of residence depends on the amount of income tax that they have to pay. Self-employed are more responsive to the tax stimulus than dependent employees and retirees. For this last group, the provision of public services plays a more important role than taxation in the residence decisions. Feld and Kirchgässner could not find any evidence that homogenization of the population brought any efficiency improvement. Fiscal competition, on the other hand, has not harmed decentralized income redistribution.

When origin-based commodity taxes are used, a jurisdiction may attract consumers, rather than residents, by setting its tax rate below that of neighboring units. In this case, residents of higher tax areas can escape taxation by incurring

${ }^{3}$ It should be noted, however, that social assistance expenditures are a small fraction of total expenditures. 
the transportation cost necessary to purchase the private good in the low-tax jurisdiction. They will do so whenever the tax differential exceeds the extra cost incurred.

Though cross border trade and distance selling have always posed a problem to tax designers, the recent expansion of the electronic commerce made its solution more pressing. O ne such solution is the adoption of destination-based commodity taxation. In this case, cross-border shopping and e-commerce would compete in equal conditions with local retailer's sales. $\mathrm{N}$ onetheless, destination principle schemes are administratively difficult to implement ${ }^{4}$.

When business, capital income or property taxes are in force in decentralized government units, depending on economic conditions, tax exporting may occur. Income and property taxes may be exported to foreign owners of domestic companies or land. Business taxes may be shifted, through increases in the prices of local output, to residents of other jurisdictions who consume the goods. Tax shifting is more likely when a locality produces a highly specialized commodity, like natural resources or touristic attractions. When tax exporting occurs, residents of a particular area do not bear the full cost of the public goods that the local government provides. This may give rise to inefficient overprovision of these goods.

Brazilian municipalities provide a case in which tax exporting is preceded by tax base importing. These units levy a tax on services that is origin-based. The tax base is determined nationally by means of a list of taxable services; and municipalities are autonomous to set the tax rate. M ost units charge a rate of (or near) $5 \%$; but some that, in normal conditions, would have barely any tax base charge a lower rate, say $2 \%$ or less, in order to attract tax base. $N$ ote that, different from the type of fiscal competition to be considered later on, the lower rate does not attract investment or production to the territory of the unit but only the fiscal residence of the firm. To qualify as a resident, all a firm needs, besides a signboard, is a rented room with a chair, a table, a telephone and an attendant, costs which may be shared with several other firms. After the tax base is imported, business continues to take place elsewhere; but the tax on the services there rendered and consumed is paid to the municipality where the "headquarters" is located.

$V$ ertical tax competition may provide additional revenue to a subnational government at no extra costs for its constituency whenever central and decentralized units impose a tax on the same tax base and the low er level tax may be credited against federal tax liability. If the compensation takes the form of a deduction from the federal tax base, there will be some increase in the overall burden faced by the taxpayer. This may result in a reduction of the tax base available to both units, amplifying the loss of revenue of the central government and reducing the gain of the decentralized unit.

As noticed in Wilson (1999), the negative externality imposed by the

${ }^{4}$ On the design of such schemes, see [Poddar, 1999; Varsano, 2000; Bird and Gendron, 2000; M CLure, 2000 and Keen, 2000. 
subnational unit - reduction of the tax base - does not necessarily imply that, in the new equilibrium, taxes are inefficiently too high. Under certain conditions, the federal government may use its policy instruments to partially offset inefficiencies at the subnational level or, in some cases, to achieve even an efficient equilibrium.

A nother form of lowering payments by residents for public services is to compete for access to funds provided at low or no cost by higher levels of government. Shah (2001) notes that these funds are often allocated by programs which objectives are vaguely specified and that lack focus on service delivery and accountability to residents. This may give rise to pork barrel politics and waste. $\mathrm{H}$ e illustrates his arguments with examples, from Brazil and Pakistan, in which the president (prime minister) directed a substantial parcel of disposable resources to his (her) home state (district); and from South Africa, where provinces strategically overspent in local functions and then claimed they had no funds to provide national functions such as health and education, which they administer. Of course, this is not to say that intergovernmental transfers are undesirable. $\mathrm{O} n$ the contrary, well-defined grants play important functions in federal systems, including that of counteracting possible ill effects of fiscal competition.

\subsection{Competition for business investment}

Fiscal competition may have the objective of attracting business investment, to increase production, the level of employment and income within thejurisdiction. Passive competition - with the use of different non-benefit tax burdens being explained, for example, by differences in tastes - may lead to the same or the opposite result. Instruments of this type of competition may be the tax structure, the expenditures mix, and regulatory policies, as well as tax incentives and public services provided to specific firms.

Tax competition through lowering the corporate income tax has been one of the major fiscal issues in the European Union (EU) for many years. Those who fear that fiscal competition will bring taxes on capital income to unduly low levels claim some degree of tax coordination. A nother numerous group takes theopposite view that tax competition is welfare improving and, therefore, the corporate income tax should not be harmonized.

Zodrow (2001) provides an overview of what the economic literature has to say in support of each of these opposite views. Z odrow starts from a basic model (Z odrow and M ieszkowsky, 1986) that, under a set of assumptions, concludes that tax competition leads to an inefficiently low level of public services in all jurisdictions. $\mathrm{N}$ ext, he reviews a wide variety of extensions of the basic model that alter one or more of its assumptions. The results are mixed: some identify potential gains and other losses from tax competition and little is said about their magnitude. Coupling these results with the observable reluctance of countries to give up their fiscal sovereignty and with the fact that some countries would be net losers from tax harmonization, Zodrow concludes that the case for it is 
tenuous. He suggests that modest initiatives, like the Code of C onduct on Business Taxation (European Commission, 1997), instead of attempts at full harmonization of the income tax, should be preferred.

Unfettered tax competition in the EU brings in, however, a concern about the future of redistributive policies in the area (Sinn, 1994; O ates, 2001). Though redistribution should be assigned preferably to central governments, European Community budget is too small to provide such programs and there is the intention of keeping it small in the future. Therefore, each of the members of the EU will have to support its own programs. The contention is that increased factor mobility in the $E U$, in the absence of income tax coordination, will force countries to rely more heavily on benefit taxation, which rules out redistribution programs, or to incur a significant cost in terms of economic growth by taxing mobile factors to finance such programs. Furthermore, as capital supply is generally more price-elastic than the labor supply and skilled labor is more mobile than unskilled, it may be expected that a wage tax will fall more heavily on unskilled than on skilled labor and that taxation of capital income will be low, resulting in a more regressive tax system.

A nother interesting question, addressed by Keen and M erchant (1997), concerns the composition, rather than the level, of public spending in a context of fiscal competition. They divide public spending in two categories, utilityenhancing - either public goods which are complements to private consumption, like recreational facilities, or redistributional payments to some poorer groups and production-improving - public inputs, like infrastructure or general training. Since they assume that citizens are immobile and firms are mobile, their conclusion is quite intuitive: in their own words, "fiscal competition leads to too many business centers and airports but not enough parks or libraries".

$\mathrm{H}$ as this trend been observed in federal systems? And what is the impact of expenditure competition among countries in a world with increasing mobility of capital across borders? Those are open questions. But K een and $M$ erchant's result suggests that there is a case for coordination not only of taxes on mobile bases but also of domestic public expenditures.

A case may also exist for coordination of regulatory policies. The purpose of regulation is to remedy market failures such as externalities and monopolistic power. But it can affect the competitiveness of a jurisdiction. In particular, if profit-maximizing manufacturers take into account the compliance costs of local regulation, governments may use lax regulation to attract business to the territory of the unit. For example, there is a stream of the literature on fiscal competition that looks at the impact of environmental regulations in business location (Levinson, 1996). In addition, the design of the financial regulation potentially can be used as an instrument to attract portfolio investment. Since banking regulations are usually set at federal level, such competition generally takes place among sovereign governments.

Instead of lowering taxes in an attempt to attract business, decentralized governments may resort to the concession of tax incentives, subsidies and provision of public inputs to specific firms. These are typical regional development policy 
instruments. When used for decentralized industrial policies, they may bring about a destructive competition. The so-called fiscal war among Brazilian states may illustrate this point.

The practice of reducing state value-added taxes to attract investment has been unlawful in Brazil since 1975, except in cases in which the intended reduction is unanimously approved by the 26 states and the Federal District. Y et, the law has been disregarded and tax competition among Brazilian states has intensified since the beginning of the nineties. Foremost among many cases is the dispute for the wave of new automotive vehicle industrial plants that have looked for a location in the country since $1995^{5}$.

From the standpoint of any particular state, granting fiscal incentives to attract investment seems worthwhile. Unless the beneficiary would choose to locate his business in the state even in the absence of the incentive, the amount of tax revenue forgone would not exist anyway. Plus, aside from their direct impact on production and employment, newly attracted firms induce additional economic activity, creating still more jobs and income, and, of course, some tax revenue.

If this werethe wholestory, state tax incentive would bea valuable development tool. But, when other states replicate the successful experience of one of them, a destructive tax competition starts.

As the practice of granting incentives spreads out, its efficacy fades. Since taxes have been equally reduced everywhere, the fiscal benefit ultimately loses its power to induce relocation of production. But revenue goes down in all states. When the process reaches this stage, firms choose their location considering only market and production conditions.

Pressed by larger spending and smaller tax collection, the financially weaker states, which are the less developed, become unable to provide services and public works necessary to attract new business. At the final stages of the fiscal war, the more developed states win all battles. Disparities - already very large in the case of Brazil - naturally tend to increase.

The fiscal cost for the country of the tax war is very high. A recent dissertation that analyzes three cases of newly installed vehicle factories (Silva, 2001) concludes that, in two of the cases, the present value of the stream of subsidies exceeds the value of the private investment; and the fiscal cost of creating a job is over US\$ 350,000 .

Furthermore, this does not seem to be a cost incurred to attract investment to the country. The plants would probably be located in Brazil in the absence of the tax break $^{6}$. Rather, this is the cost of attracting the investment to one particular

\footnotetext{
${ }^{5}$ This and the next few paragraphs on Brazilian states fiscal war draw from M ora and Varsano (2001). ${ }^{6} \mathrm{~A}$ possible but improbable alternative location, given that the market to serve is chiefly the $M$ ercosur, would be Argentina. If this alternative had, in fact, been considered and discarded because of the incentives, the fiscal cost cannot be said to be in vain. But Brazilian states policy would be unduly inflicting a loss on the partner.
} 
location within the country that, if the incentive had been truly effective, would not be the one recommended by efficiency considerations.

An implicit assumption of most of the preceding discussion is that governments are benevolent, i.e., they act in the best interests of residents of the jurisdiction. The public choice literature contends that a more realistic assumption is that government officials and politicians have their own objectives, acting in their own interest or serving the purposes of pow erful interest groups. In both these cases, instead of maximizing the welfare of the population, they will seek to maximize the size of the government budget. Under this assumption, tax competition has the welfare-improving role of counteracting Leviathan state tendency to overexpansion. In this context, harmonization of tax policies would serve the interest of the bureaucrats, assuring monopoly pow er to keep government revenue higher than it otherwise would be?

\section{SOM E EM PIRICAL EVIDENCES}

Do firms and individuals - as beneficiaries of welfare programs, consumers of public and private goods or factor owners - respond to fiscal stimuli? This is an important question. A negative answer would mean that one should not expect benefits - nor should worry about costs - of fiscal competition. Though there is substantial theoretical material on how economic agents react to tax and expenditure differences across jurisdictions, there is not much empirical work strictly related to the elasticity of the tax bases in relation to observed differences in the pattern of public spending or taxation.

O ne extensively debated question in the literature on expenditure competition is whether there is welfare-motivated migration, that is, whether or not welfare recipients move from low to high-benefit jurisdictions. Considering the case of welfare migration across US states, six out of a sample of eight studies found evidence of migration, though two of them concluded that its magnitude is small ${ }^{8}$. In contrast, Walker (1994) and Levine and Zimmerman (1995) could not detect any evidence of welfare migration. H ence, the evidence is moderately in favor of the hypothesis that migration exists, which may indicate that states in the US are in a non-cooperative equilibrium, underproviding relief to their poor compared to what would be the optimal outcome. However, the sensitivity of migration to welfare benefits is not high. M eyer (1998), for example, found that a US $\$ 1,000$ increase in the annual welfare benefit raises migration of single women to a region by only 6 percent over a five year period ${ }^{9}$.

\footnotetext{
${ }^{7}$ Some formal Leviathan type models are presented in Sinn (1992), Edwards and Keen (1996), R auscher (1998) and Gordon and Wilson (2001).

${ }^{8}$ Southwick, 1981; Blank, 1988; Peterson and Rom, 1988; Borjas, 1997; Enchautegui, 1997; M eyer, 1998.

${ }_{9} \mathrm{M}$ ost of these studies are based on the AFDC (Aid to Families with Dependent Children), in which money is given to the single mother. M eyer (1998), for example, finds that single mothers migrate
} 
Instead of reducing the overall w elfare spending, states may protect themselves from in-migration of the poor by limiting the access to the public goods. This is generally done by restricting the status of residence. $O$ ne can say that welfare spending becomes a club good, since it is possible to exclude some individuals from its consumption. Such action reduces the incentives for the poor to move and, as a consequence, should lead to higher welfare transfers compared to a situation without any exclusion. Evidence of such restrictions is common in the US history ${ }^{10}$. The existence of eligibility conditions may partly explain why the empirical studies do not find larger effects of welfare benefit differences on migration of the poor.

The studies of Figlio et al. (1997) and Saavedra (1998), instead of looking at the responses to differences in welfare transfers, test directly the existence of strategic interdependence between different states ${ }^{11}$. They provide strong evidence that benefit levels in nearby states affect a given state's benefit level choice.

Turning to tax competition, since there are not many federal systems where subnational governments have great freedom to set tax rates, the existing evidence pertains to a few countries. OECD countries for which there is enough data available are the US, Canada, Germany and Switzerland. Even in Germany, the local taxing autonomy is mainly confined to the business tax. M ost of the literature does not test the existence of tax competition, but the sensitivity of a given tax base to the level of the tax rate.

There is a vast set of empirical studies looking at the impact of capital taxes on several different measures of business activity. M ost of the studies are applied to the US, studying the impacts of differences in income tax rate across states, and differences in property taxation within a given state. Table 1 summarizes the results found in a survey for the US (W asylenko, 1997). The cells of the table report the number of studies where an elasticity measure were estimated, the number of those studies in which the tax elasticity was statistically significant (in parenthesis), the range of elasticity estimates (in brackets), and the median elasticity.

more readily in response to higher welfare benefits than do single women without children, who are not eligible for the benefit. This is an additional evidence of welfare migration.

${ }^{10}$ Brueckner (1999) observes that some states imposed severe restrictions by denying any welfare benefits to poor migrants over a waiting period as long as one year. Such restrictions were struck down by the Supreme Court in 1969, but states responded by instituting a "two-tier" benefit scheme, under which the benefits earned by migrants during their waiting period corresponded to the benefit level in their state of origin". The most known case is that of W isconsin, which protected itself against migration from Illinois, a traditionally less generous state.

${ }^{11}$ In the presence of fiscal competition, one should expect strategic complementarity among governments. For example, when the neighbor increases the tax rate on capital, the given state (or country, or municipality) will act in the same direction, and vice versa. 
Table 1: Summary of Econometric Results of Tax Effects on Bussines Location

\begin{tabular}{|c|c|c|c|}
\hline \multirow[b]{2}{*}{ Dependent Variable } & \multicolumn{2}{|c|}{ Interregional or Interstate Studies } & \multirow{2}{*}{$\begin{array}{c}\text { Intra-regional } \\
\text { Studies }\end{array}$} \\
\hline & $\begin{array}{c}\text { Overall } \\
\text { Tax Elasticity }\end{array}$ & $\begin{array}{l}\text { Business } \\
\text { Tax Elasticity }\end{array}$ & \\
\hline \multicolumn{4}{|c|}{ Aggregate Data } \\
\hline Total Employment & $\begin{array}{c}6 \text { studies }(5) \\
{[-0.85,0]} \\
-0.58\end{array}$ & $\begin{array}{c}3 \text { studies (2) } \\
{[-0.16,0]} \\
-0.11\end{array}$ & $\begin{array}{c}4 \text { studies (3) } \\
{[-1.95,-0.81]} \\
-1.95\end{array}$ \\
\hline $\begin{array}{l}\text { Manufacturing } \\
\text { Employment }\end{array}$ & $\begin{array}{c}13 \text { studies (8) } \\
{[-1.54,0.05]} \\
-0.10\end{array}$ & $\begin{array}{c}2 \text { studies (1) } \\
{[-0.26,0]}\end{array}$ & $\begin{array}{l}1 \text { study (1) } \\
-0.79\end{array}$ \\
\hline $\begin{array}{l}\text { Investment in } \\
\text { Manufacturing }\end{array}$ & $\begin{array}{l}6 \text { studies (3) } \\
-0.60 \text { or } 0\end{array}$ & $\begin{array}{c}7 \text { studies }(6) \\
{[-0.36,-0.10]} \\
-0.20\end{array}$ & \\
\hline $\begin{array}{l}\text { Gross State Product, } \\
\text { Income or Value Added }\end{array}$ & $\begin{array}{c}12 \text { studies }(7) \\
{[-0.88,0.27]} \\
-0.07\end{array}$ & $\begin{array}{c}1 \text { study }(0) \\
-0.14\end{array}$ & \\
\hline \multicolumn{4}{|c|}{ Micro Data } \\
\hline $\begin{array}{l}\text { Manufacturing Plant } \\
\text { Births or Location }\end{array}$ & $\begin{array}{c}3 \text { studies (2) } \\
{[-0.40,0]} \\
-0.19\end{array}$ & $\begin{array}{c}19 \text { studies (15) } \\
{[-15.7,0.6]} \\
-0.20\end{array}$ & $\begin{array}{c}5 \text { studies (4) } \\
{[-2.70,0.62]} \\
-1.59\end{array}$ \\
\hline
\end{tabular}

Estimates in Table 1 indicate what is the percentage decrease in the dependent variable when the tax rate in a given location is $1 \%$ higher than in a nearby location. For example, the impact of a business tax $1 \%$ higher in a given state, compared to other states, is a $0.11 \%$ decrease in employment in that state (column 2 , line 1). The main conclusions are:

- Estimates of response to tax differentials vary widely. Intra-regional differences in tax rate have a larger impact on business location than differences across states (or interregional). The intuition is that once the locality is chosen (a set of regional attributes, like agglomeration, cost of labor, size of the market, quality of education, infrastructure of transportation, etc), the specific location (in which neighborhood or suburb) will be strongly determined by tax aspects ${ }^{12}$.

\footnotetext{
${ }^{12}$ At the intra-provincial level, two papers concerning tax competition in Canada should be mentioned. Locke and Tassounyi (1996) found that business migrates from metropolitan Toronto to the vicinities, which charge lower non-residential property tax. Slack (1994), looking at data from 0 ntario, inferred that higher non-residential property taxes may discourage businesses location in a given municipalities. She also concluded that property tax differentials are not a major factor in the decision to locate in one metropolitan area or another; but once a metropolitan area is chosen, they affect the decision about in which specific municipality to locate.
} 
- The wide range of the elasticity estimates has less to do with the type of activity being measured than with the variations in data, time periods, and other variables used in the estimation equation. In effect, the results change depending on which variables are included in the estimation equation or which time period is analyzed.

- In particular, adding controls for the type and level of public good supplied by each location affects significantly theeconometric results. Business-friendly regulations and public spending that enhances productivity enable a given location to set a higher capital and/or property tax rate. In other words, local attributes increase the "tax setting power" of a given jurisdiction and should be taken into account when estimating business responses to tax differences.

In a different line, some studies test the existence of strategic complementarity on business tax setting between jurisdictions. Ladd (1992) find statistical support for the hypothesis that neighboring jurisdictions mimic each other's tax policy in the US. Büttner (1999) tests the existence of tax competition from the relationships between the levels of capital income tax rate in German districts. As in Ladd (1992), he finds evidence that tax rates are positively related to neighbors' tax rates $^{13}$.

Some evidence on cross-border shopping may also be found in the empirical literature on tax competition. Due and M ikesell (1994) find, for US data, that a one percent differential in sales taxes results in a shift from one to six percent of purchases from higher to lower tax areas. In Canada, a study of this phenomenon found little evidence of cross-border trade in the O ttawa-H ull area in the 1970's, when the inter-provincial rate differential was 3\% (D ufour and Vaillancourt, 1982).

In Europe, some regimes of tax exemption for non-residents lead to "crosscountry" shopping. For example, in the Schleswig-Holstein border between Denmark and Germany, Germans use to buy car in Denmark while Danishes buy spare parts in Germany. This is a consequence of regulation and taxation, which lead to completely different final prices in the two countries (Economist, 11/29/01).

\section{HOW TO COPE WITH FISCAL COM PETITION?}

A challenge facing areas - countries, unions or even the whole world where fiscal competition develops is how to reduce the welfare loss from its several facets without sacrificing the benefits of decentralization.

\footnotetext{
${ }^{13}$ The explanation for a positive correlation between tax rates in a neighborhood may be a result of classic competition, since the tax base is volatile. Alternatively, this might be a result of political competition. Voters compare policies in the neighboring district with those of their own district. The mayor does not get re-elected if his (or her) policy happens to be worse than the one in the neighbor district (Besley and Case,1995).
} 
A country may impose restrictions on beggar-thy-neighbor policies, by means of a constitutional provision or national laws that bind the decentralized units. Restrictions, how ever, may be difficult to enforce. Authorities would have to keep track of a large assortment of fiscal instruments, including disguised ones. It would be difficult to distinguish whether these instruments were directed to competition or to other objectives that they can also serve. And long judicial battles might be necessary to determine whether or not the act of one decentralized unit caused any damage to the affairs of another. Besides, there is the risk of putting welfare-enhancing competition in the same bag and prevent it as well.

A high degree of centralization of taxing powers coupled with transfers to decentralized units, as is the case of A rgentina, or the assignment of tax legislation to the federal government, as in Germany, are possible solutions. They have in common the shortcoming of eliminating oneimportant facet of federalism, namely, the autonomous determination of the size of the budget of each subnational unit. Vertical coordination - tax collection agreements, tax base sharing, abatement of subnational from federal taxes - , extensively used in Canada, results in more uniform tax bases, leaving space for decentralized decision on the size of the budget but also for some competition.

Intergovernmental transfer mechanisms may be designed to reduce detrimental effects of fiscal competition without sacrificing the benefits of decentralization. The theory of fiscal competition is concerned with the existence of externalities generated by the action of a given jurisdiction over the residents of another, and with the consequences when tax and expenditure decisions do not take such externalities into account. Economic theory prescribes the use of a system of interjurisdictional transfers such that a given unit pays taxes for the negative spillovers and receives subsidies for the positive spillovers that it promotes. Such "Pigouvian" transfer system would theoretically drive the system to an efficient decentralized equilibrium (Varian, 1992). Unfortunately, implementation of this ideal transfer scheme is impossible and federal countries use non-optimal schemes.

In the case of expenditure competition, the underprovision of transfers to the poor resulting from decentralization may be partially offset by earmarked grants from the central to subnational governments. Such is the case of the decentralized provision of public education and health in Brazil, as well as that of US states direct assistance to the families below poverty line.

Earmarked transfers may be either in the form of block grants or matching grants. Under the block grant, each jurisdiction receives a lump-sum amount from the central government whose magnitude is independent of the level of jurisdiction contribution to the provision of the public good. Under the matching grant, individual jurisdictions determine the level of expenditure and the central government pays a fixed share of a jurisdiction's total outlay. The theory of expenditure competition prescribes a matching-grant system because it reduces the marginal cost (faced by the states) of providing welfare programs, leading to a higher equilibrium level of expenditure. Under the block grant system, states 
would tend to spend only the amount of the lump sum transfer coming from the Central Government ${ }^{14}$.

$\mathrm{H}$ armonization of fiscal policies may also be used as a tool to reduce the negative effects of fiscal competition, preserving, however, the advantages of decentralized policies. In the case of unions, where "central governments" has a very small budget and decentralized units are sovereign jurisdictions that cannot be legally bound, except by voluntary subscription of a treaty, harmonization may well betheonly feasible instrument to cope with fiscal competition undesirable effects.

Fiscal competition is, as mentioned in the introduction, an extreme case in which members of a federation act independently, without any scope for cooperation. $\mathrm{H}$ armonization is a move to a position in which some cooperation exists. This may range from token coordination, which is presently the position with respect to EU corporate income taxes, to full integration, a position in which the units give up their autonomy or sovereignty, as is the case of the monetary policies of European M onetary Union (EM U) countries.

$M$ uch has been said about the need for harmonization of fiscal policies among the European countries as they engage in deeper integration. And much has been said against harmonization, particularly by those who believe in Leviathan. But even discarding the hypothesis that harmonization will be the instrument to assure big government, it must be recognized that the implementation of such coordination scheme is far from trivial, specially in the economic union.

First, a contract among sovereign countries must consider a wide range of possible non-cooperative strategies that should be ruled out. It is probably impossible to cover every alternative. For example, harmonization of the tax structure may be put at risk by lenient enforcement in a given jurisdiction.

Secondly, when dealing with sovereign countries, such "federalist pact" is not enforceable in case some party decides to act non-cooperatively. H ence, the building of an organism with roles of supervision and enforcement must precede the design of such a contract. The question is: are EU members prepared to give up their fiscal sovereignty? This is a sine qua non condition to deepen the harmonization process.

The answer to this question is contingent on a number of factors, important among them the answer to another question: how much are the gains to be reaped from tax coordination? There are few answers to this question in the economic literature, most of them provided in the context of highly simplified models.

Sorensen (2001) developed a tax competition model that relaxes many of the restrictive assumptions of previous modeling efforts, in an attempt to provide more reliable guidance to policy makers. Sorensen uses the model to offer quantitative

\footnotetext{
${ }^{14}$ The US welfare reform of 1996 transited from a matching grant to a block grant system, and gave more freedom to the states to define their own policies. Brueckner (1999) argues that this switch may cause a reduction in welfare spending in the long run, and could only be corrected by going back to the matching grant mechanism.
} 
estimates of the welfare gains from tax coordination. He considers the cases of global coordination - all countries in the world coordinate their tax policies and of regional coordination - only a subset of countries (the "union") coordinate their policies. $\mathrm{H}$ is main conclusions are " that the gain from regional tax coordination is only a small fraction of the potential gain from global coordination if capital mobility is perfect. With imperfect capital mobility between the tax union and the rest of the world, there is greater scope for regional tax coordination, although the welfare gain will almost certainly be well below 1 percent of GDP and will accrue mainly to countries with high initial capital income tax rates." In short, the reward for surrendering fiscal sovereignty seems to be too low.

\section{A SUM MING-UP AND A NOTE ON GLOBALIZATION}

Fiscal competition is a natural companion of decentralization. Potentially, it always exists, since it is the consequence of differences among jurisdictions, not necessarily of intentionally promoted discrepancies; and there are no two identical government units in the world. Practically, fiscal competition manifestation depends on the intensity of the divergences and on the reaction of the economic entities in face of the array of options offered by decentralization.

Fiscal competition takes several forms, uses a diversity of instruments and may bring about a number of different outcomes (section 2). An impressive quantity of theoretical work tries to model the phenomenon. O verall, the results are quite sensitive to the set of assumptions that is adopted in the analysis. Therefore, there are results to almost all tastes. The state of the art, as expressed by Wilson (1999), is that "competition among governments is now seen as a less straightforward phenomenon than perhaps originally envisioned." And, of course, there is space for further modeling, with the introduction of complexity that may approach the ideal to the real world.

Proving the practical existence of fiscal competition and verifying its impact on factors of production and consumers movements across jurisdictions (section 3 ) is an important step. Knowledge about the effects of competition on the economic agents and on the intensity of their reaction to the fiscal stimulus is helpful for the conception of mechanisms to curb or to invigorate government competition, whichever is the case. But which is the case?

The insight brought in by what may be called the traditional tax competition models is that tax competition tends to distort the allocation of resources, promoting welfare losses. Accepting that these losses exist, they should bew eighted against possible gains from expenditure competition - e.g., ideal environment for public policy innovations and a closer match between public goods provision and local preferences - that are concomitant. The existing literature provides almost no evidence on the magnitude of these gains and losses. Further research on this difficult empirical problem is necessary to fill this fundamental gap.

In the absence of clear-cut conclusions from both the theoretical and the 
empirical literature, the wisest attitude toward fiscal competition seems to be the avoidance of extreme measures either to impede or to enhance competition. $\mathrm{H}$ ence, controls or recentralization may be welfare-reducing measures insofar as they eliminate political competition among jurisdictions or create the environment for the Leviathan to rise. Of course, the best course of action is, whenever possible, to adopt measures that reduce w elfare losses without sacrificing the benefits of decentralization. Carefully designed intergovernmental transfers and cautiously conducted harmonization processes seem to be the more promising instruments (section 4).

Finally, some conjectures should be made on the impacts of globalization of economic activities fiscal competition. Globalization and regional integration restrain fiscal sovereignty insofar as factor mobility and growing trade flows require that domestic policies, including taxation, follow more closely the international patterns. Homogenization of central governments practices may induce decentralized units to assume the task of attracting foreign direct investment, by increasing the provision of local public inputs. Furthermore, international competitiveness is increasingly contingent on the existence of skilled labor, which depends on education and training outlays that are typically decentralized government functions.

Therefore, it should be expected that fiscal competition intensity will increase in the near future and that subnational units will be competing not only among themselves but also in the world market. They will probably bypass the national governments and negotiate directly with firms the location of their business.

Given that skilled labor, infrastructure and other local public inputs are tokens in these negotiations, less developed regions of a country - and in the world - will be in disadvantage. Regional disparities (as well as personal income concentration) will tend to increase, what suggests that central governments and international institutions - should amplify their personal and regional redistributive efforts in order to neutralize this undesirable trend.

\section{REFERENCES}

Blank R. M . (1998) "The Effect of W elfare and W age Levels on the Location Decisions of FemaleH eaded H ouseholds". J ournal of U rban E conomics 24, pp. 186-211.

Besley T. and A. Case (1995) "Incumbent Behavior: Vote-Seeking, Tax Setting, and Yardstick Competition". A merican Economic Review 85(1), M arch.

Bird R. M . and P.-P. Gendron (2000) "CVAT, VIVAT, and Dual VAT: Vertical Sharing and Interstate Trade". International Tax and Public Finance 7, no. 6, pp. 753-761.

Borjas G. J. (1997) Immigration and W elfare M agnets. H arvard University. mimeo.

Brueckner J. K. (1999) "W elfare R eform and the Race to the Bottom: Theory and Evidence. University of Illinois - Urbana-Champaign. mimeo.

Büttner T. (1999) "D eterminants of Tax Rates in Local Capital Income Taxation: a Theoretical M odel and Evidence from Germany" - CESifo W orking Paper Series N o. 194, September.

Due J. and J. L. M ikesell (1994) Sales Taxation: State and Local Structure and Administration. W ashington: Urban Institute Press.

Dufour J.-M . and F. Vaillancourt (1982) "Provincial and Federal Sales Taxes: Evidence of Their 
Effect and Prospects for Change". In Wayne R. Thirsk and John Whalley (eds.), Tax Policy O ptions in the 1980s. Canadian Tax Foundation.

Edwards J. and M. Keen (1996) "Tax Competition and Leviathan". European Economic Review 40, pp. 113-134.

Enchautegui M . E. (1997) "W elfare Payments and O ther D eterminants of Female M igration" . J ournal of L abor E conomics 15, pp. 529-554.

European Commission (1997) "Toward Tax Co-Ordination in the European Union: A package to Tackle H armful Tax Competition". COM (97) 495 final.

Feld L. and G. Kirchgässner (2000, "Income Tax Competition at the State and Local Level in Switzerland". CESifo W orking Paper Series N 0. 238, January.

Ferreira S. G. (2002) "M unicípios: D espesa com Saúde e Transferências Federais" . Informe-SF N o. 38. Área de Assuntos Fiscais e de Emprego / BN DES.

Figlio D. N ., Van W. Kolpin and William Reid (1997) "Do States Play W elfare Games?" . Journal of Urban Economics.

Gordon R. H . and J. D. Wilson (2001) "Expenditure Competition". N ational Bureau of Economic Research W orking Paper 8189, M arch.

Keen M . (2000) "VIVAT, CVAT, and All That: N ew Forms of Value Added Tax for Federal Systems". Canadian Tax Journal vol.18, no. 2, pp. $409-424$.

Keen M . and M . M archand (1997) "Fiscal Competition and the Pattern of Public Spending" . Journal of Public Economics 66, pp. 33-53.

Ladd H. (1992) "M imicking of Local Tax Burdens among N eighboring Counties", Public Finance Q uarterly 20,4, pp. 450-467.

Levine P. B. and D. J. Zimmerman (1995) "An Empirical A nalysis of the W elfare M agnet D ebate Using the N LSY". N ational Bureau of E conomic R esearch W orking Paper N 0. 5264.

Levinson A. (1996) “Environmental Regulations and M anufacturers' Location Choices: Evidence from the Census of $M$ anufacturers". Journal of Public E conomics 62, pp. 5-29.

LockeW . and A . T assounyi (1996) “Local T ax BaseEndogeneity and T ax Competition: a consideration of the Greater Toronto Area". Paper presented in the Canadian Economics Association Annual $M$ eeting, Brock University, O ntario.

M cL ure C. E. Jr. (2000) “Implementing Subnational Value Added Taxes on Internal Trade: The Compensating VAT (CVAT)". International Tax and Public Finance 7, no. 6, pp. 723-740.

M eyer B. (1998) "D o the Poor M igrate to Receive H igher W elfare Benefits?" . N orthwestern University. mimeo.

M intz J and H . Tulkens (1986) "Commodity T ax Competition between M ember States of a Federation: Equilibrium and Efficiency". Journal of Public Economics 29, pp. 133-172.

M ora M . and R. Varsano (2001) "Fiscal Decentralization and Subnational Fiscal Autonomy in Brazil: Some Facts from the N ineties", IPEA, Texto para D iscussão N 0. 854, December.

$O$ ates W . (1972) Fiscal Federalism, H arcourt Brace, N ew York.

O ates W. (1999) "An Essay on Fiscal Federalism", J ournal of E conomic Literature, vol. XXXVII, pp. $1120-1149$

O ates W. E. (2001) "Fiscal Competition and European Union: Contrasting Perspectives" . Regional Science and U rban E conomics 31, pp. 133-145.

O ates W. E. and R. Schwab (1988). "Economic Competition among J urisdictions: Efficiency Enhancing or Distortion Inducing?" . Journal of Public Economics 35, pp. 333-354.

Peterson P. E. and M . C. Rom (1998) "The Case for a N ational W elfare Standard". Brookings R eview. pp. 24-32.

Poddar S. (1999) " Considerations in the Design of a VAT at the State Level in India". Paper prepared for the VAT Seminar for Senior O fficials from the Centre and the States, July.

Rauscher M . (1998) "Leviathan and Competition among J urisdictions: the Case of Benefit Taxation". Journal of U rban Economics 44, pp. 59-67.

Saavedra L.A. (1998) "A M odel of Welfare Competition with Empirical Evidence from AFDC". Journal of Urban Economics.

Shah A . (2001) "Interregional Competition and Federal Cooperation - To Compete or to Cooperate? That's not the Q uestion". Paper presented at the International Forum on Federalism in M exico: Local and Global Challenges. Vera Cruz, M exico, N ovember. 
Silva M . A. (2001) Guerra Fiscal e Finanças Federativas no Brasil: o Caso do Setor A utomotivo. Universidade Estadual de Campinas. M aster dissertation.

Sinn H .-W . (1994) "H ow M uch Europe? Subsidiarity, Centralization and Fiscal Competition”. Scottish Journal of Political Economy 41, pp. 85 -107.

Sinn S. (1992) "The Taming of Leviathan: Competition among G overnments" . Constitutional Political Economy 3, pp. 177-196.

Slack E. (1994) "Non-Residential Property Taxation and Competitive Advantage in the Greater Toronto A rea". Canadian Urban Institute, Urban Focus Series no.94.

Sorensen P. B. (2001) "International Tax Coordination: R egionalism versus G Iobalism". CESifo Working Paper N 0. 483, M ay.

Southwick L. Jr. (1981) "Public W elfare Programs and Recipient M igration". G rowth and Change 12 , pp. 22-32.

Tiebout, Charles (1956) "A Pure Theory of Local expenditures" . Journal of Political Economy 64, pp. 416-424.

Varian H. (1992) M icroeconomic A nalysis. N ew Y ork: W.W N orton \& Co. Third edition.

Varsano R. (2000) "Subnational Taxation and the Treatment of Interstate Trade in Brazil: Problems and a Proposed Solution". In S. J. Burki et al. (eds.) D ecentralization and Accountability of the Public Sector. Proceedings of the Annual Bank Conference on Development in Latin A merica and the Caribbean. Washington, D. C.: W orld Bank, pp. 339-356.

Walker J. R. (1994) "M igration among Low Income H ouseholds: H el ping the W itch Doctors Reach Consensus". Institute for R esearch on Poverty - University of Wisconsin-M adison. M imeo.

Wasylenko M ., (1997), "T axation and Economic D evelopment: the State of the Economic Literature". $\mathrm{N}$ ew England Economic Review, M arch/A pril.

Wildasin D. E. (1988) "N ash Equilibria in M odels of Fiscal Competition" . J ournal of Public Economics 35, pp. 229-240.

Wilson J. D.,(1999) "Theories of Tax Competition". N ational Tax Journal 52, pp. 269-304.

Zodrow G. R. (2001) "T ax Competition and Tax H armonization in the European Union". Paper presented at a conference on "Tax Policy in the European Union", The $\mathrm{H}$ ague, O ctober.

Zodrow G. R. and P. M ieszkowski (1986) "Pigou, Tiebout, Property Taxation, and the Underprovision of Local Public Goods". J ournal of U rban Economics 19, pp. 356-370. 